4-16-2021

\title{
Inventing a Space to Speak: Ethos, Agency and United States' Woman Suffrage Cookbooks (1886-1916)
}

Danielle Nielsen

Murray State University, dnielsen@murraystate.edu

Follow this and additional works at: https://digitalcommons.murraystate.edu/faculty

Part of the Arts and Humanities Commons

\section{Recommended Citation}

Nielsen, D. (2021). Inventing a Space to Speak: Ethos, Agency and United States' Woman Suffrage Cookbooks (1886-1916). Gender \& History. https://doi.org/10.1111/1468-0424.12530

This Journal Article is brought to you for free and open access by Murray State's Digital Commons. It has been accepted for inclusion in Faculty \& Staff Research and Creative Activity by an authorized administrator of Murray State's Digital Commons. For more information, please contact msu.digitalcommons@murraystate.edu. 


\section{Inventing a Space to Speak: Ethos, Agency and Woman Suffrage Cookbooks}

In the forward to the Suffrage Cook Book (1916), the editors promise 'The recipes were, for the most part, contributed by Detroit suffragists, and may help to show again what has been so often

demonstrated before, that an interest in politics is not incompatible with an interest in cookery ${ }^{\text {' }}$. This thin volume, only 121 pages of recipes with additional front matter, index and advertisements, was one of a handful of suffrage cookbooks. The cookbook's front matter succinctly articulates its purpose: the title page includes the title Suffrage Cook Book and a seal depicting Lady Justice encircled with the phrase 'VOTES FOR WOMEN'. A secondary title page identifies the authors as the Equal Suffrage League of Wayne County, Michigan. The foreword, three short paragraphs, admits it is not a 'complete' cookbook, reaffirms its commitment to politics and the home and thanks contributors, many of whom are identified by name with their recipes.

Between 1886 and 1916, suffrage groups around the United States published community cookbooks like this one to raise money for and awareness of women's suffrage. Modern cookbook scholarship in sociology and history generally recognises Hattie Burr's Woman Suffrage Cook Book (1886) as the inaugural suffrage cookbook. The Rockford, Illinois, Equal Suffrage Association's Holiday Gift Cook Book (1891), Linda Deziah Jennings' Washington 
Women's Cook Book (1909), M.B.S. Hoar's Enfranchised Cookery (1915), L.O. Kleber's Suffrage Cook Book (1915), the Clinton, New York, Political Equality Club's Choice Recipes Compiled for the Busy Housewife (1916), and the previously mentioned Suffrage Cook Book followed. ${ }^{2}$ The women who published these cookbooks argued they could simultaneously engage with American civic life and maintain their homes.

Unlike some of the better-known speeches like Elizabeth Cady Stanton's 1848 Seneca Falls address, Susan B. Anthony's 'Is it a Crime to Vote?,' given on a speaking tour after her arrest for casting a ballot in the 1872 presidential election, and Carrie Chapman Catt's 1917 Address to Congress, which put women directly in the public sphere, cookbooks positioned suffragists in the kitchen, a space aligned with the expectations of the Cult of True Womanhood. This ideology embodied behavioural standards by which predominantly white, middle-class women were expected to live; specifically, they were expected to exhibit 'piety, purity, submissiveness and domesticity' ${ }^{3}$ Middle-class Victorian society idealised women who kept house, educated children and provided a welcoming and loving atmosphere for their families. Because of these ideals, middle-class women were expected to remain in the private sphere, but as the nineteenth century progressed, their social and personal interests increasingly intersected with those in the public sphere. Throughout the nineteenth century, as women's literacy increased, their rhetorical instruction and participation increased as well. Genres like 
conduct manuals and cookbooks provided an ideal participatory avenue for women who were expected to adhere to the Cult of True Womanhood and, at the same time, who desired to contribute to the national conversation. Cookbooks in particular enabled women to 'participate, through the culturally acceptable privacy of the domestic sphere, in public discourses regarding issues of race, class, gender, region, and religion'. ${ }^{4}$ Cookbooks included information about which women held expertise: cooking, housekeeping, childrearing and tending to the infirm. Importantly, sharing information with one another, even in publicly published forms, did not seem to infringe upon the expectations of the Cult of True Womanhood. In addition to demonstrating expertise and engaging in public discussions, cookbooks allowed women to create communities; suffrage cookbooks in particular created a community that was simultaneously revolutionary and conservative. Suffragists called upon the nation to expand enfranchisement, and cookbooks themselves 'define[d] the 'ideal' woman as a middle-class mother', who, to become the 'ideal' mother, should 'imagine themselves as part of a larger, benevolent community and frame their tasks as a means to satisfy cultural need ${ }^{5}$ For the suffragists who compiled cookbooks, the 'cultural need' simultaneously represented protecting and guiding both the literal home, the conservative community, and the more metaphorical national home, the revolutionary community. 
This article expands contemporary scholarship on suffrage cookbooks by examining the books' decidedly domestic rhetoric, both the language used and spaces built within the covers of the cookbooks. It contributes to calls within rhetorical scholarship that urge us to look beyond the outspoken, public suffragists like Susan B. Anthony to those who continued to work within the private sphere. This article argues the predominately white, middle-class compilers of suffrage cookbooks used audience expectations of the genre of community cookbooks to create both a 'rhetoric of space' and ethos. 'Rhetorics of space' are 'those material and discursive practices that work to compose and enhance a space. Rhetorics of space explain what the space should be, what it should do, and what should go on inside it' ${ }^{6}$ Because the Cult of True Womanhood located women physically in the home, the cookbook provided suffragists with a rhetorical space to connect with those interested in maintaining the illusion of separate spheres but who also desired suffrage. Compilers strategically used reader expectations of cookbooks and the Cult of True Womanhood to further calls for woman suffrage. Thus, Victorian-era cookbooks embodied a seemingly straightforward purpose and a clear rhetoric of space: they taught women to cook and care for the home. Suffrage cookbooks, with their arguments in favour of women's enfranchisement, expanded these discursive practices, particularly when considering 'what should go on inside it' when they included specific calls to expand the franchise. 
Moreover, these women used their ethos as homemaking experts to create a sense of shared values among audience members who may have been hesitant about participating in the suffrage movement and, consequently, acting or speaking in or adjacent to the public sphere. Cookbook contributors used their personal agency to develop their ethos from the socially acceptable location of the kitchen. This home-bound ethos allowed the suffragists to simultaneously advocate for women's suffrage, their 'interest in politics', and maintain their adherence to the Cult of True Womanhood because their activism was grounded in expected feminine actions, their 'interest in cookery'. ${ }^{7}$ Burr's Woman Suffrage Cook Book appeared more than forty years into the suffrage fight, and subsequent cookbooks repositioned suffrage arguments in this new rhetorical space to quell fears about women's agency outside the home.

\section{Using location to develop ethos}

Feminist rhetoricians' recent scholarship, particularly that which focuses on the rhetors' location and personal agency to develop ethos, helps to elucidate the suffrage cookbooks' potential to manipulate the expectations of the Cult of True Womanhood. Risa Applegarth's 'Genre, Location, and Mary Austin's Ethos', Patricia Bizzell's 'Frances Willard, Phoebe Palmer, and the Ethos of the Methodist Woman Preacher', Karlyn Kohrs Campbell's 'Agency: Promiscuous and Protean', Julie Nelson Christoph's 'Reconceiving Ethos in Relation to the Personal: Strategies of 
Placement in Pioneer Writing', Sonja Foss's 'Rhetorical Criticism as Synecdoche for Agency', Casey Ryan Kelly’s ‘Women's Rhetorical Agency in the American West: The New Penelope’, and Nedra Reynolds' 'Ethos as Location: New Sites for Understanding Discursive Activity' all examine ethos in women's writing. ${ }^{8}$ Applegarth, Bizzell, Christoph, Kelly and Reynolds explore women's texts of the nineteenth century. The women who produced the suffrage cookbooks and those included in these studies are similar in both time and place, if not in purpose.

Works from the United States produced during the nineteenth century have proven rich for contemporary scholarship on women's rhetoric. During this time, middle-class women moved with increasing frequency between the private and public spheres. Those like Willard and Palmer spoke at religious gatherings; westward expansion, as explored in Christoph's, Kelly's and Applegarth's scholarship, saw women challenging gender expectations; and because more women were literate, there is simply more textual sources. While rhetorical scholarship recognises a number of prominent suffragists' speeches and writings, little rhetorical research has focused on the suffrage cookbooks, providing scholars with another way to understand how the suffragists hoped to persuade their audiences. This work also answers Carol Mattingly's call in 'Telling Evidence: Rethinking What Counts in Rhetoric' to consider suffragists beyond Susan B. Anthony and Elizabeth Cady Stanton. She notes that because Anthony and Cady Stanton used rhetorical strategies similar to those of their male contemporaries, more attention has been paid 
to them than to other women who may not have produced logos-driven or linearly argumentative texts. ${ }^{9}$ In contrast to these traditionally linear arguments, this article examines how middle-class women drew on their ethos by locating themselves as speakers in the kitchen, often a focal point of the private sphere, to persuade the nation that suffrage benefited everyone, men and women.

Rhetors develop or constitute ethos from their social context, location and call to shared values. To most effectively develop this appeal, the women paid close attention to the rhetoric of the spaces from which they spoke. In describing the nineteenth-century schoolroom as a feminine sphere, Jessica Enoch defines the 'rhetorics of space' as 'those material and discursive practices that work to compose and enhance a space. Rhetorics of space explain what the space should be, what it should do, and what should go on inside it' ${ }^{10}$ Reynolds further aligns space and ethos: 'The classical notion of ethos, therefore, as well as its contemporary usage, refers to the social context surrounding the solitary rhetor ... Careful attention to the etymology of ethos its connections to space, place, or location - helps to reestablish ethos as a social act and as a product of a community's character'. ${ }^{11}$ Where the rhetor is, who the rhetor is speaking to and what values that community holds, the 'social context' or 'rhetorical space', all determine accessible ethos. Applegarth provides another way to think about community expectations and locational ethos: 'Ethos traces a boundary between individual, strategic performance and the constraints of social norms'. ${ }^{12}$ The 'boundary' creates metaphorical spaces that rhetors and their 
audiences inhabit through their values. To conceptualise ethos, Applegarth and Reynolds look specifically to how communities develop 'boundaries' or rhetorical spaces that delimit rhetors' persuasive actions. For a rhetor to successfully persuade their audience through ethos, their rhetorical positioning of and in the space should follow the audience's expectations. The space that a rhetor inhabits can be a literal space, such as a religious institution, schoolroom or a kitchen, or a more metaphorical space, like a newspaper or cookbook.

In addition to rhetors speaking from the same space as their audience, they must also show that they share their audience's values. Christoph explains the relationship between ethos and shared values, noting that 'The interactive nature of the ethos that the Aristotelian speaker constructs in the speech is such that the ethos is more a testament to communal values than to any privately held values of the speaker' ${ }^{13}$ Ethos becomes interactive because the Aristotelian rhetor 'inspires confidence' by demonstrating 'good sense, good moral character, and goodwill'. ${ }^{14}$ The audience recognises the rhetors' 'good sense, good moral character, and goodwill' by measuring whether the speaker's values align with their own. If the values do not align, the audience will not recognise the rhetors' ethos. Moreover, the values must be made public through the rhetor's presentation. If the audience cannot determine whether the values are shared, then the rhetor loses the appeal to shared values. 
To be most persuasive rhetors should locate themselves in the space that allows the most interplay between their own and the communal values, interpreting 'ethos as location, grounded in material spaces and drawing persuasive power from the shared symbolic resonance of such spaces'. ${ }^{15}$ The space itself has its own ethos, and the audience's attention to the 'symbolic resonance' includes their awareness of the space's communal values. For example, a religious leader or congregant speaking within a place of worship is expected to uphold that community's shared values. If the rhetor speaks against those values, it will be more difficult to construct an ethos because of the space's symbolic and rhetorical power. In other words, if the value systems and the location align, the rhetor can more easily develop ethos, and the audience is more likely to find her credible - the rhetor has 'inspired confidence' in herself and her message. If the values differ and/or the space is inappropriate, then the rhetor will lack the character needed to be persuasive to that audience. To 'inspire confidence' or construct their ethos, rhetors must find a way to position themselves within the community's value systems. Location is key.

Not only do location and shared values inform the rhetor's ethos, but they make measuring that ethos possible. Ethos cannot be assessed outside of the social context or the location which informs those values because ethos is an interactive appeal. ${ }^{16}$ If social context, including location, determines a rhetor's likely success at 'inspiring confidence' in the audience and developing ethos that will make her more persuasive, then she is necessarily bound by that 
social context. But, what happens if a rhetor seeks to change specific communal values, such as women's right to vote? This constraint does not mean the rhetor will always be placeless or destined to fail. Rather, ethos 'requires negotiation between individual rhetorical choices [agency] and meaningful social categories' ${ }^{17}$ Rhetors, use their agency, to manipulate and build the spaces from which they speak. Campbell admits that 'authors/rhetors are materially limited, linguistically constrained, historically situated subjects'. ${ }^{18}$ The social context and spaces from which rhetors speak necessarily constrain their ability to develop ethos. But 'at the same time, they are 'inventors' in the rhetorical sense, articulators who link past and present, and find means to express those strata that connect the psyche, society, and world, the forms of feeling that encapsulate moments in time'. ${ }^{19}$ Rhetors use their knowledge of the social context - the constraints within which they work - to shape the spaces they need. Through a negotiation between their own agency and the constraints they face, rhetors can create spaces, like the ancillary materials in cookbooks, that exhibit shared values and allow them to 'inspire confidence'.

\section{Using cookbooks and community to create a rhetorical space and ethos}

Suffragists used community cookbooks to locate themselves in an argumentatively palatable environment, increasing the likelihood that they would share values with their readers and 
increase their appeal to ethos. Community cookbooks became popular when women's groups wanted to raise funds to provide relief to wounded soldiers through the Sanitary Commission of the Union Army. ${ }^{20}$ After the war, religious groups, hospitals and aid organisations for women, children, elderly and disabled patients issued charity cookbooks as fundraisers and, in the aftermath of the Civil War, 'staked the nation's future on bolstering local networks within a broader cosmopolitan American culture' ${ }^{21}$

Community cookbooks became a hallmark of women's civic participation. Most often, women wrote these cookbooks to participate in local, 'cosmopolitan American culture'. In addition to raising funds, the work women performed to create and circulate these recipes 'demonstrate[d] the participation of the women [. . .] in the creation of that society'. ${ }^{22}$ As women moved out of the private into the public sphere, cookbook readers acknowledged women's agency in developing physical and rhetorical communities. During the second half of the nineteenth century, women became more involved in volunteer organisations where they 'sought personal development, friendship, cultural stimulation, and opportunities for public life'. The community cookbook cemented these relationships in a public venue. ${ }^{23}$ 'At a time when American women were without full political rights and representation', Janice Longone argues, women 'found the community cookbook one very effective way to participate in the public life of the nation'. ${ }^{24}$ The community cookbook, then, allowed women to gather together around a 
common cause, advocate for change and participate in the public sphere in ways that their cultural milieu approved.

In addition to helping women shape communities, cookbooks also helped them connect with one another. Floyd and Forster explain 'Through the discovery, reading and even putting into practice of other women's recipes an imagined community is built. Real communities too are expressed and documented through recipes, and modes of cookery, or cookbooks'. ${ }^{25}$ 'The exchange of recipes and the naming of contributors' develops these real communities and 'cements relationships fostered in daily life. It is one way to signal and affirm affiliations. Women's cookbooks could and have represented alliances and affinity, and often have been based on shared characteristics of race, class, and religion'. ${ }^{26}$ Nussel expands on Theophano's categories to include neighbourhood associations and political and social organisations, like suffrage groups. ${ }^{27}$ These organisations allowed women to find like-minded people in their communities, and cookbooks publicly emphasised communities' values. These communal values underscore the importance of the cookbooks' ancillary materials. While recipes can illustrate socio-economic status and food availability within the community, it is the forewords, epigraphs and editorial notes that make clear the sponsoring organization's espoused values. Without this information, these books would be collections of recipes rather than artefacts which clearly identify women 'participat[ing] in the public life of the nation' ${ }^{28}$ The First Unitarian Church of 
San Francisco's Cookery Blue Book and the Spencer, Iowa, Trinity Lutheran Church's Lutheran Church Women's Cookbook, for example, identified sponsoring organisations through author and title. Readers were expected to recognise these communities' religious values and ideologies.

Suffrage cookbooks similarly emphasised community, civic engagement and values. Jennings' Washington Women's Cook Book; the Rockford, Illinois, Equal Suffrage Association's Holiday Gift Cook Book; and the Clinton, New York, Political Equality Club's Choice Recipes Compiled for the Busy Housewife, like the church cookbooks, all identified location through titles or authorship. Cookbooks also included advertisements from local businesses that allowed readers to recognise the intended audience's or community's 'class, neighborhood, and religious dynamics'. ${ }^{29}$ The Equal Suffrage League's Suffrage Cook Book promoted advertisers like caterer Karl E. Heberlein, Burnham's Art and Stationery Shop, complete with circulating library, and Detroit Creamery Milk. The compilers informed the readers of their 'careful selection': 'As in the body of this book careful selection has been made to include only well tried and proven recipes, so in the advertising pages like care has been taken to include only high-class companies, and commodities of proven worth and value'. ${ }^{30}$ With phrases like 'high-class companies' and 'commodities of proven worth and value,' the advertisements' preface indicated the socio-economic status and location of intended audiences. Advertisers like a caterer, The Electric Store, which sold electric appliances, and a Stationery Shop and Lending Library, 
identified the intended audience as Wayne County's middle class. The advertisements also indicated the audience was local to Detroit as most of the services or products offered were those that would be used in homes rather than ones travellers might use.

Not all community cookbooks were limited to local audiences, and suffrage cookbooks were no exception, especially given the national, and at times international, nature of the suffrage movement in the United States and Great Britain. Increased speed in mail delivery and telegraphy allowed suffragists to communicate with one another. Burr's Woman Suffrage Cook Book indicated that while the cookbook supported the Boston-based groups, the suffrage question was international. The Woman Suffrage Cook Book's title page indicated its sales were 'in aid of the Festival and Bazaar, December 13-19, 1886,' and the 'CCountry Store,' April 2126, 1890'. ${ }^{31}$ The cookbook, however, included contributors from a number of states and England. Alongside this list of contributors were three advertisements: subscription information for the Woman's Journal, the official newspaper of the American Woman Suffrage Association, with testimonials from Louisa May Alcott, Clara Barton and Frances Willard; mailing information for 'Woman Suffrage Tracts', also published by The Woman's Journal; ${ }^{32}$ and an ad for Magee Standard and Mystic Ranges, a Boston-based stove company whose goods were 'For sale by our agents in every City and large Town in the U.S. ${ }^{33}$ The advertisements created a defined 
community of suffragists in Boston who would receive the proceeds, but they also invited women from across the United States to be part of their community.

These cookbooks exhibited the main components of community cookbooks and illustrated why suffragists may have turned to this genre. First, the cookbooks highlighted the women's communities, namely the suffrage movement. Second, the cookbooks allowed women to become part of civic society and participate in the 'creation' of that society as they identified contributors, sold books and created relationships. Third, as will be discussed next, cookbooks created a rhetorical space from which the suffragists could convincingly speak to those who resisted calls for universal suffrage. This rhetorical space reinforced middle-class Victorian gender expectations, spurring the use of 'expediency arguments' and allowing suffragists to develop an ethos that more closely matched that audience's communal values.

\section{Responding to social constraints: The 'antis' and the Cult of True Womanhood}

Though rhetoricians have historically defined ethos as an attribute of personal agency, suffragists derived ethos from their own agency and their position in the kitchen. To maintain their ethos as 'true women', cookbook compilers argued against contemporary justice arguments that advocated suffrage as an equal right. Instead, they used expediency arguments to claim woman suffrage would maintain societal norms, specifically the expectation that women serve as moral 
arbiters. The cookbook compilers positioned themselves as conservative women protecting the home through suffrage.

These expediency arguments placed cookbook compilers in direct conversation with those opposing woman suffrage, activists commonly known as 'antis'. Antis resisted justice arguments and advocated maintaining separate spheres, ensuring women remained 'pure' and free from what they saw as the immoral political world. Suffrage, they argued, would necessarily introduce women to this world. Some antis argued women should only campaign for causes that affected women and children or could improve the morality of those around them. When women contributed in this way, antis argued, they still worked within the confines of the domesticity and morality of the Cult of True Womanhood. ${ }^{34}$ Many antis, alongside suffragists, were active in the temperance and pure food movements and, thus, they were not entirely opposed to women's civic engagement (and ironically moved into the public sphere through this work).

Food purity and temperance obviously affected men, women and children. By the end of the nineteenth century, however, both causes were often viewed as women's issues. Holly Berkeley Fletcher explains the transition, noting the 'self-made man', an icon of the antebellum temperance movement, was 'a statement of the exclusivity and authority of white, middle-class manhood'. After the Civil War, however, this masculine figure was often overshadowed by the 'crusading woman'. 35 The effects of alcohol directly aligned with women's experiences. 
Domestic and sexual violence and poverty were closely associated with alcoholism and affected women's ability to maintain the clean, moral homes middle-class values articulated. Similarly, although the Pure Food movement included both men and women, leading proponents such as the General Federation of Women's Clubs used 'a maternalist language, with adulterated food a threat to their protective family roles and pure food a special responsibility of the nation's women' ${ }^{36}$ Whether an anti or a suffragist, middle-class women drew from their socially and locationally constructed ethos to argue for a 'special responsibility' to protect their home and children.

The difference between engagement with temperance or pure food and suffrage was explicit interaction with politics and legislative action outside of women's acknowledged expertise. With suffrage, women might participate in, or vote on, considerations of war, for instance. Antis argued war did not concern women because they did not serve as soldiers; thus, to cast votes about war would allow women to make decisions about situations in which they did not participate, despite the fact that the deaths and injuries of male relatives necessarily affected women.

One argument antis used played directly into the hands of suffrage cookbook creators. Antis argued that if women gained suffrage, they would relinquish their housekeeping duties, especially cooking. The antis emphasised cooking in their protestations and 'argued that women 
involved in the campaign for the vote lacked culinary skills, failed to cook for their husbands, and did not care that their children went hungry in their absence'. Antis accused suffrage campaigners who travelled on behalf of the movement of being neglectful mothers. ${ }^{37}$ If women could vote, the antis argued, then home life would suffer. Antis asserted that disenfranchised women provided the support that men needed to sufficiently protect the nation. In short, according to the antis, suffrage weakened the domestic space and threatened the nation.

Rhetorically, justice arguments based on equal rights caused the audience to lose faith in the suffragists' ethos because the audience did not accept, or could not be persuaded, that men and women were equal. Expediency arguments, however, enhanced the suffragists' ethos. Specifically, by writing from the kitchen, suffragists realigned their arguments with their readers' values and spoke from a position of influence. By speaking from a socially acceptable space, they bolstered the more revolutionary suffrage argument.

Because antis reinforced separate spheres, justice arguments that advocated for equal rights for men and women would necessarily fail to recruit readers who agreed with the antis. Suffrage cookbooks, however, spoke directly to the fears that woman suffrage would cause the destruction of the middle-class household. As the movement evolved, some suffragists turned to expediency arguments, which 'held that women should be permitted to vote because they, unlike men, were the caregivers and the nurturers of society, and these abilities would make women 
valuable contributors to understanding and solving society's problems, especially those confronting families, women, and children' ${ }^{38}$ Rather than focusing on justice arguments' male and female equality, expediency arguments contended women's feminine roles as caretakers and moral representatives would improve the increasingly industrial and modern American society. Men's lack of housekeeping and care skills, these arguments put forth, made them less able to solve the nation's growing problems. The Washington Women's Cook Book declares 'Give us a vote and we will cook / The better for a wide outlook', directly linking suffrage with cooking quality and explicitly linking women's responsibilities in the home to the suffrage movement. ${ }^{39}$ This overt concern with justice and expediency arguments, morality and women's and men's natures highlights the complexity of suffrage, the moral double standard and the accompanying 'woman question' under debate at the fin de siècle. Neither suffrage nor the woman question can be easily situated under the umbrellas of conservative or progressive politics. While there were certainly suffragists who saw the need for the destruction of the moral double standard, which held that women were expected to maintain higher morals than their husbands, others, like the cookbook compilers, saw the continued discrepancy as a rhetorical advantage.

In addition to arguing suffrage would improve the home, suffragists used women's growing philanthropic participation in moral and social concerns to advocate for the relationship between cooking and good citizenship practices, directly refuting the antis' claims that suffrage 
would weaken the nation. They used ancillary materials in their cookbooks to respond to the growing tide of anti-suffrage press and worked to persuade women who were uncertain of crossing the threshold into the public sphere. For instance, in The Suffrage Cook Book's introduction, Erasmus Wilson connects eating, citizenship and the success of the nation:

Eating and drinking are so essential to our living and to our usefulness, and so directly involved with our future state, that these must be classed with our sacred duties. Hence the necessity for so educating the children that they will know how to live, and how to develop into hale, hearty and wholesome men and women, thus insuring the best possible social and political conditions for the people of this country. ${ }^{40}$

Suffragists, male and female alike, made their argument clear: good homemakers educated children and served their families healthy foods. In turn, these healthy families worked to 'insur[e] the best possible social and political conditions for the people of this country'. Communities needed strong 'social and political conditions', and the recipes in this cookbook were 'a dependable guide to a most desirable social, moral and physical state of being' supported by 'the members of Equal Franchise Associations'. ${ }^{41}$ In the cookbooks, suffragists argued that 
suffrage and civic engagement did not embolden women who 'lacked culinary skills, failed to cook for their husbands, and did not care that their children went hungry in their absence', ${ }^{42}$ but rather, suffrage and civic engagement encouraged precisely the opposite; women, with their vote and their housekeeping, would best care for families and communities. In fact, if the Washington women were to be believed, their cooking, or their adherence to the Cult of True Womanhood, would even improve with full suffrage because of their greater understanding of the world around them.

\section{Stirring it all together: Crafting middle-class values through recipes and suffrage rhetoric}

Suffrage cookbooks foregrounded the white, middle-class community. Despite the fact many early suffragists were also abolitionists, suffrage cookbooks' created a rhetorical space that excluded women of colour. This exclusion ran through the movement, for noted suffragists, including Susan B. Anthony and Elizabeth Cady Stanton, made clear distinctions between middle-class white women like themselves and women of colour. Though the Nineteenth Amendment was ratified in 1920, Native Americans and those of Chinese descent would not gain full suffrage until years later (1924 and 1943, respectively), and then poll taxes and literacy tests prevented many people of colour from fully exercising their rights. Suffrage cookbooks reasserted this racial divide. Mann notes the 'dominance of white and affluent women's voices in 
suffrage cookbooks and hunger strikes', ${ }^{43}$ and Elias explains that community cookbooks in particular 'shared a palate, or a set of flavours, and a methodology that allows us to see what a large number of white, middle-class people considered their proper cuisine' ${ }^{44}$ For Walden, this 'shared palate' participates in the rhetorical and philosophical discourse of 'taste'. The rhetoric of taste is primarily constrictive and prescriptive, teaching people to act appropriately. Specifically, throughout the eighteenth and nineteenth centuries these lessons centred around citizenship practices of white men and women. ${ }^{45}$ Thus, arguments put forth in the cookbooks, especially those that link women's actions to the Cult of True Womanhood, are arguments that, when contextualised in the historical, cultural and social moment of the fin-de-siècle, support middle-class white women's suffrage more than universal suffrage for all American citizens, including men and women of colour.

The recipes' 'shared palate' also illustrated middle-class communities and foodways: recipes indicate foodstuffs available and the popularity of dishes and demonstrate how suffragists participated in shaping cookbooks. If suffragists used the cookbook as a rhetorical space from which to draw and develop ethos, it only makes sense that recipes reflected the eating, cooking and baking habits of the intended (communal) audience, just as ancillary materials explicitly advocating suffrage highlighted those values. 
Because these cookbooks catered to white, middle-class families in America their use would have varied; some users and contributors may have been responsible for their own housekeeping and cooking responsibilities, for others, household labour may have been employed. Wilson anticipates the Suffrage Cook Book to be used by families explaining that because 'Women [are] the homekeepers, and the natural guardian of the children, it is important that they be made familiar with the culinary art so they may be entirely competent to lead coming generations in the paths of health and happiness ${ }^{46}$. Burr similarly anticipates families cooking from her text but warns that the recipes in the Woman Suffrage Cook Book may or may not be 'original'; she promises, however, 'each has been thoroughly tested, and is vouched for as reliable by the contributor whose name is appended' ${ }^{47}$ While modern readers do not know who was cooking or developing the recipes, we do know these cookbooks were expected to be used to by families. They were, in other words, being used by the suffragists as exemplars of middleclass taste and expectations and providing evidence that suffragists portrayed the communal values to which their readers adhered.

Two cookbooks published thirty years apart illustrate the evolution of taste, recipe design and ingredient availability within these communities. During the fin de siècle, recipes evolved from single paragraphs, where ingredients and instructions mingled, to a list of ingredients followed by a paragraph of instruction. Both Burr's Woman Suffrage Cook Book (1886) and the 
Equal Suffrage League of Wayne County's Suffrage Cook Book (1916) include multiple recipes for brown bread, what might be called 'whole wheat' or 'whole grain' bread today. Mrs. Zilpha Spooner's recipe in the Woman Suffrage Cook Book follows the singular paragraph format:

Two cups of Indian meal, two cups of rye meal, one cup of flour, one large cup of molasses, one teaspoonful of soda. Mix soft with warm water. Steam five hours. ${ }^{48}$

In contrast, Mrs. Charles Metcalf's recipe in the Equal Suffrage Cookbook reads:

Materials:

4 c. Graham flour, 1 tsp. salt,

2/3 c. dark molasses, 2 c. sweet milk, 2 eggs, 1 tsp. soda.

Beat eggs with salt, add the milk, and stir into flour and molasses. Last add the soda mixed with a little hot water. This makes two loaves. Bake in moderate oven from 40 minutes to one hour. ${ }^{49}$ 
Not only is the structural difference obvious, but the ingredients also illustrate changes in American food traditions. These are both 'brown bread' recipes; however, cooks familiar with baking recognise they will yield two different loaves.

Spooner's mixture of Indian meal (corn meal), rye and wheat in fairly large quantities indicates their widespread availability, at least for the middle class. Further, the integration of corn meal continues the colonial trend of adapting native American grains, like corn, to traditional English baking. The lack of eggs and milk make this an economical choice for the middle-class cook concerned with being a financially prudent housekeeper. In steaming rather than baking, this recipe will yield a dense, chewy, fairly sweet loaf, consistent with Boston brown bread even if the location moniker is not used.

In contrast, Metcalf's recipe uses only Graham flour, a wholewheat flour popularised by the mid-century nutritional reformer Sylvester Graham. The dough is also enriched with eggs and milk, and baked rather than steamed. In comparison to Spooner's loaf, it will be lighter in texture and flavour because of the milk, eggs and cooking method. The sole use of Graham flour might indicate the lack of availability of other flours or this home cook's devotion to the Graham dietary movement that privileged vegetarianism, whole grains and temperance.

Moreover, the recipes suggest differing levels of expertise to successfully execute them. Spooner's recipe relies on the cook's intuition to know how much water to add and how to steam 
the loaf. Metcalf's recipe provides slightly more instruction, clearer measures and the note that it will make two loaves, though additional water is still needed. Thus, seemingly simple recipes for brown bread (two of multiple recipes under the same name in both cookbooks) highlight characteristics of the cookbooks' users like culinary knowledge, personal economy, healthy eating habits and the availability of refrigeration to keep milk and eggs, illustrating the intended audiences' values as compatible with those of the middle-class Cult of True Womanhood.

The cookbooks' ancillary materials further articulated these middle-class values. It was common for 'introductions,' for instance, to 'set a tone and [help] the reader see herself as part of a particular culture with assumptions and expectations in common with social peers' ${ }^{50}$ In the first sentences of the preface to Woman Suffrage Cook Book, Burr used her agency to set the tone: 'This volume is sent out with an important mission. It has been carefully prepared, and will prove a practical, reliable authority on cookery, housekeeping, and care of the sick, especially adapted to family use'. ${ }^{51}$ In this excerpt, she illustrated her constraint and her ability to be an 'inventor', and she signalled the domestic values she and the contributors shared with their audience. The cookbook's 'important mission' was not to encourage suffrage. Rather, it was designed to be a 'reliable authority' for a woman's domestic duties 'especially adapted to family use'. Similarly, the Washington Women's Cook Book preface reminded readers 'cooking represents the evolution of civilized life', and the recipes in the cookbook represented 'science, 
art and the human desire to produce things beautiful'. This civilised life, according to Jennings, corresponded with 'Home, a smiling woman, and a good dinner' because 'does not the heart of man yearn toward this trio at evening time?'. ${ }^{52}$ Burr and Jennings spoke to the fears of the antis: women who voted would desert their families. To quell that fear, they showed suffragists would use their authority as wives and mothers to care for their families, in sickness and in health. Both women used the rhetorically popular triad to highlight domesticity and ensure their readers' attention: Burr's 'cookery, housekeeping, and care of the sick' and Jennings' 'home, a smiling woman, and a good dinner' clearly signified the domestic values of the Cult of True Womanhood, focusing the reader's attention on the shared understanding of the importance of taking care of one's home and family.

\section{Carving out a rhetorical space in the suffrage kitchen}

Not only did the cookbooks reaffirm communal values, but suffragists also spoke from a place where seemingly divergent value systems could interact: the home, and more specifically, the kitchen. To successfully persuade, suffragists needed to decide on the most useful rhetorical strategy that would position them within or alongside the value systems of the target audience. It was not enough that the cookbooks espoused these values, they must be seen as holding them as well. Applegarth describes this strategic location as a process in which 'rhetors learn to enact 
culturally specific notions of "good will, good sense, and good moral character" through their participation in particular communities and their habituation, within places, to shared norms that make ethos effective'. ${ }^{53}$ In their opening paragraphs, Burr and Jennings wrote to the 'particular communities' they needed to persuade by situating themselves in the audience's preferred rhetorical space.

By writing from and working in the kitchen, women who feared suffrage meant abandoning domesticity saw suffragists working within the expected boundaries. Cindy Koenig Richards explains the Washington Women's Cook Book 'publicized political views together with pragmatic information and regional norms. As such, it generated interest and participation even from women who did not identify themselves as suffragists' ${ }^{54}$ Including housekeeping, cooking information and 'regional norms' made the text rhetorically accessible to non-suffragists. To highlight regional norms, for instance, Washington Women's Cook Book included 'Sailors Recipes' and recipes for wild game native to the Pacific Northwest. ${ }^{55}$ Residents in inland states would have little use for information on how to prepare seal heart or whether shark tail was an appropriate food source. The cookbook underscored the community's coastal nature and its values of responsibly using the food and supplies available. These recipes indicate the location of the community, its values around food use and the foodstuffs available to local families. Furthermore, the highly local information makes it clear to readers the compilers are part of their 
community and not outsiders. This regional information was situated beside pro-suffrage epigraphs like Alice Stone Blackwell's assertion that 'women should votes [sic] Because it is fair and right that those who must obey the laws should have a voice in making them', which opens the 'Beverages' chapter. ${ }^{56}$

Jennings drew on the expectations of a community cookbook to reflect the norms or values of the represented community so that she could open a rhetorical space to 'generate interest' from those who might not call themselves suffragists. ${ }^{57}$ This rhetorical situatedness reaffirmed middle-class women's societal expectations and rhetorical constraints: women at home, keeping house, not outside the home agitating. In performing these values, suffragists developed an appropriate ethos for that space and community. Initially, the women needed to show they upheld domestic values so they did not alienate those readers for whom those values held precedent. Their calls to women as housekeepers, mothers, wives and caretakers, and the emphasis of those responsibilities above all else, created a rhetorical space and opened dialogue that privileged domesticity.

By physically locating women in the kitchen and drawing on the expectations of the Cult of True Womanhood, suffragists created a feminine persona and drew on what their peers expected to be women's expertise: domesticity and femininity. This use of a feminine persona, 'that of teacher, mediator or layperson, rather than that of expert, leader, preacher, or judge' 58 , 
was also part of the appeal to a diverse audience who at first disagreed with woman suffrage. Women taught, organised and ensured peace. These characteristics coincided with expediency arguments that asserted women should have the right to vote because through that vote, they would improve society. The ancillary materials reminded readers that as voters women would contribute to the public good. The epigraph to the Washington Women's Cook Book vegetables chapter, for instance, asked 'What is politics? Why it's housekeeping on a big scale. The government is in a muddle, because it has been trying to do the housekeeping without the women' ${ }^{59}$ Here, the epigraph's writer acts as an instructor, presenting her readers with a question 'What is politics?' Knowing that her readers may have a variety of answers, she presented her own to guarantee they have the correct one. This epigraph presented the cookbook as a space where readers were taught about politics through a question and answer, and it firmly situated women's roles in politics through their domesticity. By likening politics to housekeeping, and proclaiming that the government was 'in a muddle' because women were not involved in governance, the Washington Women's Cook Book located itself in physical (the house) and rhetorical (Cult of True Womanhood/rhetoric of domesticity) spaces that made the argument more palatable. Jennings furthered this argument when she cites Jane Addams' comparison of voting and women's work: 'Women do not ask for the ballot as a right or a privilege, but the social and political conditions of today make it necessary that women be given 
the ballot to do their work in the world as they always have done' ${ }^{60}$ Both epigraphs suggested politics is not a separate sphere from which women should be forbidden. Rather, it is a space where women not only belonged, but were needed to fix problems addressed through political mechanisms. If, the epigraphs argued, it was enough for women to be expected to keep house, feed and care for the sick, and ensure the health and safety for others, then women had the responsibility to continue these duties on a national scale. Moreover, these arguments directly refuted justice arguments: 'the ballot' is not a 'right or a privilege'. Instead, it is an obligation akin to domestic duties. To shirk suffrage was to leave one's duties unfulfilled.

\section{Conclusion: Finding authority in the kitchen and at the ballot box}

Cookbook editors claimed women's involvement in governance was a domestic responsibility. To introduce women to the public sphere, they recognised contributors by name, an uncommon practice in charity cookbooks at the time. The feminine persona, as Campbell characterises it, is one that is helpful or a layperson; in other words, not an 'expert', as a masculine persona might present itself. By disavowing the label of 'expert', the women performed the duties of a True Woman. Yet, cookbook compilers challenged this submissiveness and enabled women to claim expertise when they identified them. Burr, for instance, called her cookbook a 'reliable authority' and, by association, those women featured in the cookbook were also 'authorities' in their 
domestic duties. The Equal Suffrage Cook Book, the Woman Suffrage Cook Book and the Washington Woman's Cook Book included the contributors' names. L.O. Kleber's The Suffrage Cook Book did not provide a contributor for each recipe, but instead included a list of contributors before the recipes. Jennings emphasised the work that went into ensuring the women were recognised writing in the Acknowledgement and Explanation 'we have tried hard that all might be represented by name'. ${ }^{61}$ Kaplan's 1976 introduction to the reissued Washington Woman's Cook Book recognised the power of naming the contributors. She reminded readers

The more we study the history of women, the more forcibly we are struck with the consistent editing out of women's names, the swallowing up of female identity, the removal of deeds from women to men ... These can be understood as political strategies designed to make us believe women are non-achievers, not up to the rough game of politics, less than capable of bearing the responsibilities of elective office, although assisting is acceptable. ${ }^{62}$

Though Kaplan speaks specifically of Jennings' choices, each time a suffrage cookbook editor included the names of contributors, they gave these women identity, agency and responsibility for their actions. This conferring of identity allowed women to be seen as 'achievers' who could 
'bear the responsibilities of elective office.' Women could, and often did, 'assist' their husbands and fathers in the political sphere, but identifying contributors moved women into the arena of 'expert' where they could be recognised for their work.

By identifying recipe authors, proclaiming expertise in the home and kitchen, and putting forth the women's responsibilities to maintain the nation and 'to do their work in the world as they always have done ${ }^{93}$, suffragists invented the rhetorical space from which they could develop an ethos that would create an understanding with their audience of their 'good will, good sense, and good moral character'. ${ }^{64}$ They could build ethos because they had 'identif[ied] the opportune moments in which material structures are open to restructuration and reinterpretation [when] ... the social order can be reformed and resignified by symbolic and material practices that engage the deep structures of patriarchy and its attendant practices' ${ }^{65}$ The genre of the community cookbook provided a 'material structure' which they could 'reinterpret' for their purposes. Specifically, they could work within the Cult of True Womanhood, or 'patriarchy and its attendant practices', to demonstrate their continued domesticity while also creating a space for themselves as experts in the kitchen and civic participants. The published cookbooks 'asserted that local women possessed expertise that was worthy of publication. They proclaimed that cooking was an enterprise that required understanding and skill'. ${ }^{66}$ The cookbooks used examples of how women would contribute to civic life by extending housekeeping to the public 
sphere, whether that was through Addams' assertion that women were already doing the work, the idea that politics was simply housekeeping on a larger scale, or that women, as civic participants would ensure clean food, safe working conditions and youth labour laws. ${ }^{67}$ By the end of the fight for suffrage, suffragists and their advocates had realised that arguments for equal rights were not always effective, as they threatened the patriarchal structure that so rigidly dominated white, middle-class America. This did not mean, however, that they gave up the fight for suffrage. Instead, suffragists used their rhetorical agency - their expertise as wives, mothers and housekeepers - to publish cookbooks from which they could argue for suffrage. Instead of arguing that men and women should be treated equally, these women worked from the Victorian expectation that women were more morally sound than their male partners, arguing that if women could vote, the nation as a whole would be healthier, both morally and physically. Wendy Sharer reminds readers that in the final years of the suffrage battle suffragists 'justif[ied] political activism by linking it to protection of the home' and that this practice 'was a common rhetorical tactic for women's political groups' because they argued 'the causes around which they organised were not political but moral and thus within women's purview' ${ }^{68}$ Suffragists invented rhetorical spaces in which they could develop an ethos that drew from the community's shared values, whether those shared values were those influenced by the Cult of True Womanhood or the values informed by woman suffrage. This rhetorical space allowed women to speak to shared 
community values without alienating those readers who may not fully approve of women's involvement in public spaces. 
${ }^{1}$ Equal Suffrage League of Wayne County, Suffrage Cook Book: A Collection of Recipes (Detroit: Equal Suffrage League of Wayne County, 1916).

${ }^{2}$ Rockford Equal Suffrage Association, Holiday Gift Cook Book (Rockford: Rockford Equal Suffrage Association, 1891); Linda Deziah Jennings (comp), Washington Women's Cook Book (Seattle: Washington Equal Suffrage Association, 1909); M.B.S. [May Bartlett Shawhan] Hoar (ed.), Enfranchised Cookery: An Offering from the Enfranchised Women Whose Names Appear Within to the Committee on Arrangements for the Forty-Seventh Annual convention of the National American Woman Suffrage Association (New York: National Woman Suffrage, 1915); L.O. Kleber (comp), The Suffrage Cook Book (Pittsburgh: Equal Franchise Federation of Western Pennsylvania, 1915); Clinton Political Equality Club, Choice Recipes Compiled for the Busy Housewife, 1916 (Clinton, New York: Courier Press, 1916).

${ }^{3}$ Barbara Welter, 'The Cult of True Womanhood: 1820-1860', American Quarterly 18 (1966), p. 152 .

${ }^{4}$ Sarah Walden, Tasteful Domesticity: Women's Rhetoric and the American Cookbook, 17901940 (Pittsburgh: University of Pittsburgh Press, 2018), p. 27.

${ }^{5}$ Walden, Tasteful Domesticity, p. 70. 
${ }^{6}$ Jessica Enoch, 'A Woman's Place Is in the School: Rhetorics of Gendered Space in NineteenthCentury America’, College English 70 (2008), p. 276.

${ }^{7}$ Equal Suffrage League, Suffrage Cook Book.

${ }^{8}$ Risa Applegarth, 'Genre, Location, and Mary Austin's Ethos', Rhetoric Society Quarterly (2011), pp. 41-63; Patricia Bizzell, 'Frances Willard, Phoebe Palmer, and the Ethos of the Methodist Woman Preacher', Rhetoric Society Quarterly 36 (2006), pp. 377-98; Karlyn Kohrs Campbell, 'Agency: Promiscuous and Protean', Communication and Critical/Cultural Studies 2 (2005), pp. 1-19; Julie Nelson Christoph, 'Reconceiving Ethos in Relation to the Personal: Strategies of Placement in Pioneer Women's Writing', College English 64 (2002), pp. 660-79; Sonja K. Foss, 'Rhetorical Criticism as Synechdoche for Agency', Rhetoric Review 25 (2006), pp. 375-9; Casey Ryan Kelly, 'Women's Rhetorical Agency in the American West: The New Penelope', Women's Studies in Communication 32 (2009), pp. 203-31; Nedra Reynolds, 'Ethos as Location: New Sites for Understanding Discursive Activity', Rhetoric Review 11 (1993), pp. $325-38$.

${ }^{9}$ Carol Mattingly, 'Telling Evidence: Rethinking What Counts in Rhetoric', Rhetoric Society Quarterly 32 (2002), pp. 99-108.

${ }^{10}$ Enoch, 'A Woman's Place is in the School,' p. 276.

${ }^{11}$ Reynolds, ‘Ethos as Location', p. 327. 
${ }^{12}$ Applegarth, 'Genre, Location, and Mary Austin's Ethos', p. 45.

${ }^{13}$ Christoph, 'Reconceiving Ethos in Relation to the Personal', p. 663.

${ }^{14}$ Aristotle, Rhetoric, p. 91.

${ }^{15}$ Applegarth, ‘Genre, Location, and Mary Austin's Ethos’, p. 43.

${ }^{16}$ Reynolds, ‘Ethos as Location’, p. 329.

${ }^{17}$ Applegarth, ‘Genre, Location, and Mary Austin's Ethos’, p. 48.

${ }^{18}$ Campbell, 'Agency', p. 5.

${ }^{19}$ Campbell, 'Agency', p. 5.

${ }^{20}$ Anne Bower, 'Our Sisters' Recipes: Exploring “Community” in a Community Cookbook', Journal of Popular Culture 31 (1997), p. 137.

${ }^{21}$ Megan Elias, Food on the Page: Cookbooks and American Culture (Philadelphia: University of Pennsylvania Press, 2017), p. 17.

${ }^{22}$ Bower, 'Our Sisters' Recipes', p. 138, emphasis in original.

${ }^{23}$ Bower, 'Our Sisters' Recipes', p. 137.

${ }^{24}$ Janice Bluestein Longone, “"Tried Receipts”: An Overview of America’s Charitable Cookbooks', in Anne Bower (ed.), Recipes for Reading: Community Cookbooks, Stories, Histories (Amherst: University of Massachusetts, 1997), p. 20. 
${ }^{25}$ Janet Floyd and Laurel Forster, 'The Recipe in its Cultural Contexts', in Janet Floyd and Laurel Forster (eds), The Recipe Reader: Narratives, Contexts, Traditions (New York: Ashgate 2003), p. 5 .

${ }^{26}$ Janet Theophano, Eat My Words: Reading Women's Lives through the Cookbooks They Wrote (New York: Palgrave, 2002), pp. 41-2.

${ }^{27}$ Jill Nussel, 'Heating Up the Sources: Using Community Cookbooks in Historical Inquiry', History Compass 4 (2006), p. 958.

${ }^{28}$ Longone, 'Tried Receipts', p. 20.

${ }^{29}$ Nussel, 'Heating Up the Sources', p. 958.

${ }^{30}$ Equal Suffrage League of Wayne county, Suffrage Cook Book.

${ }^{31}$ Hattie Burr (ed.), The Woman Suffrage Cook Book: Containing Thoroughly Tested and Reliable Recipes for Cooking, Directions for the Care of the Sick, and Practical Suggestions, Contributed Especially for this Work (Boston: Mrs. Hattie A. Burr, 1886).

${ }^{32}$ Burr, The Woman Suffrage Cook Book, p. viii. [Pg viii and page 8 are two different pages in this text. For some reason, word won't let me leave this as a comment.]

${ }^{33}$ Burr, The Woman Suffrage Cook Book p. x. 
${ }^{34}$ Thomas Jablonsky, 'Female Opposition: The Anti-Suffrage Campaign', in Jean Baker (ed.), Votes for Women: The Struggle for Suffrage Revisited (Oxford: Oxford University Press, 2002), pp. $118-43$.

${ }^{35}$ Holly Berkley Fletcher, Gender and the American Temperance Movement (New York: Routledge, 2008), p. 6.

${ }^{36}$ Jeffery Haydu, 'Frame Brokerage in the Pure Food Movement, 1879-1906', Social Movement Studies 11 (2012), p. 101.

${ }^{37}$ Jessica Derleth, “"Kneading Politics”: Cookery and the American Woman Suffrage Movement', Journal of the Gilded Age and Progressive Era 17 (2008), p. 451.

${ }^{38}$ Holly J. McCammon and Karen E. Campbell, 'Winning the Vote in the West: The Political Successes of the Women's Suffrage Movements, 1866-1919', Gender and Society 15 (2001), p. 74.

${ }^{39}$ Jennings, Washington Women's Cook Book.

${ }^{40}$ Erasmus Wilson, 'Introduction' in The Suffrage Cook Book, L.O. Kleber (comp.), (Pittsburgh: Equal Franchise Federation of Western Pennsylvania, 1915), p. 7.

${ }^{41}$ Wilson, 'Introduction', p. 8.

${ }^{42}$ Derleth, “"Kneading Politics”, p. 451. 
${ }^{43}$ Molly Mann, 'Hunger on the Homepage: Reading Suffrage cookbooks and Food Blogs',

Graduate Journal of Food Studies 5 (2018), https://gradfoodstudies.org/2018/12/11/

hunger-on-the-homepage/\#_ednref19.

${ }^{44}$ Elias, Food on the Page, p. 18.

${ }^{45}$ Walden, Tasteful Domesticity, pp. 5, 44.

${ }^{46}$ Wilson, 'Introduction', p. 8.

${ }^{47}$ Burr, Woman Suffrage Cook Book, p. iii.

${ }^{48}$ Burr, Woman Suffrage Cook Book, p. 2.

${ }^{49}$ Equal Suffrage League of Wayne County, Suffrage Cook Book, pp. 69-70.

${ }^{50}$ Elias, Food on the Page, p. 16.

${ }^{51}$ Burr, Woman Suffrage Cook Book, p. iii.

52 Jennings, Washington Women's Cook Book.

${ }^{53}$ Applegarth, 'Genre, Location, and Mary Austin’s Ethos', p. 43.

${ }^{54}$ Cindy Koenig Richards, 'The Awakening: Rhetoric and the Rise of New Women in the New

Northwest, 1868-1912' (unpublished doctoral thesis, Northwestern University, 2008), p. 186.

${ }^{55}$ Jennings, Washington Women's Cook Book, p. 142.

56 Jennings, Washington Women's Cook Book, p. 125.

${ }^{57}$ Koenig Richards, 'The Awakening', p. 186. 
${ }^{58}$ Karlyn Kohrs Campbell, 'Style and Content in the Rhetoric of Early Afro-American Feminists', Quarterly Journal of Speech 72 (1986), p. 440.

59 Jennings, Washington Women's Cook Book, p. 41.

${ }^{60}$ Jennings, Washington Women's Cook Book, p. 60.

${ }^{61}$ Jennings, Washington Women's Cook Book.

${ }^{62}$ Shirlie Kaplan, Pots and Politics: an historical cookbook: from the Suffragists to the Equal Rights Amendment (Tacoma: Washington State Women's Political Caucus, 1976), p. 7.

${ }^{63}$ Jennings, Washington Women's Cook Book, p. 60.

${ }^{64}$ Applegarth, 'Genre, Location, and Mary Austin’s Ethos', p. 43.

${ }^{65}$ Kelly, 'Women's Rhetorical Agency in the American West', p. 227.

${ }^{66}$ Richards, 'The Awakening', p. 195.

${ }^{67}$ This concern that women participate in the public sphere was supported by cookbook contributor and popular American author Charlotte Perkins Gilman, who in her novella Herland describes a peaceful, well-educated utopia where men no longer exist.

${ }^{68}$ Wendy Sharer, Vote and Voice: Women's Organizations and Political Literacy, 1915-1930 (Carbondale: Southern Illinois University Press, 2004), p. 17. 